25 per cent - not very much for an enterprise whose business is growing at more than 10 per cent a year. Given that inflation continues apace, the Post Office might consider increasing the amount of money reinvested each year from its own resources. Technically, the Post Office must live with uncertainty about its dreams for the 1980s. Will it then be possible to embark without much hesitation on the conversion of the present system to one based exclusively on digital transmission, and will the microwave trunk network then be as attractive as it now promises to be? If the Post Office were a truly commercially minded organization, it would do everything it could to remove this uncertainty, which argues for a further acceleration of the research and development programme. There might even be a case for deciding that Britain might stagger on with a less good system of telecommunications than it needs for the remainder of this decade for the sake of faster progress in the 1980s. But whatever strategic decisions of this kind may be made, there is no doubt that the planning of telecommunications in Britain should be much more closely coordinated than seems at present likely with what is happening on the mainland.

* Britain's Economic Prospects. By Richard E. Caves and Associates. The Brookings Institution, 1968.

\section{Roads and Planning}

THE Greater London Council has predictably provoked the wrath of motoring organizations in Britain by issuing last week a discussion paper, Traffic and the Environment, which floats, among other suggestions, the possibility that off-street parking places might be taxed at a rate of between $£ 150$ and $£ 250$ a year. And, of course, it is a curious phenomenon to see how the GLC has now stood on its head its old policy on parking. A decade ago, nobody could build an office block in central London without providing a certain amount of off-street parking. Now the GLC insists that each new office building may not be provided with more than a certain amount of parking and plainly it is dickering with still more draconian measures, including the taxation of offstreet parking and the requirement of supplementary licences for those who would bring vehicles into central London. The old objective of forcing parked cars off the streets has given way to the notion that moving vehicles should also be restricted. In present circumstances, and especially because the plans for building an inner ring of motorway connexions have now been lost in the fog of the public inquiry on the motorway box, there is much to be said for giving the council's proposals a serious hearing.

So far, so good. There is, however, an important sense in which the council's proposals are too narrow and too negative. It is all very well to promise that public transport will be improved, but everybody knows how long it takes to build a new underground railway, and there is at present no prospect that the underground network with which London is already equipped will be modernized (as it should be) in the foreseeable future. Worse still, however, the council seems to have been able to divorce the immediate problem of traffic congestion from the long-term question of how London as a whole should be planned. Moreover, the past few years have seen far too casual and insensitive a replacement of older parts of the city by meretricious buildings, sometimes tawdry, sometimes pretentious (like the unfortunate building south of St James's Park which Sir Basil Spence has been allowed to design, no doubt on the strength of his good connexions and his Order of Merit).

The most immediate need is for a moratorium on the tasteless renewal of central London now well under way. Old buildings of no particular architectural merit may often be, by their familiarity and their associations, important parts of the fabric of the city. If the planning authority is willing to impose a levy on off-street parking spaces, should it not also impose a much greater levy on those who wish to knock down old buildings in those parts of the city where some of the old character survives? The GLC should also set out more energetically than it has done so far to reverse the drift of ordinary people from central London to the increasingly distant suburbs -itself one of the potent generators of traffic. And for the more distant future, the planning authority should clarify in its mind a more modern concept of what a modern city should be like. The essence of any city is that those who live and work in it should be able to communicate with each other easily, not merely by telephone but face to face. In the days of the cart and the hansom cab, this could be done only if people were living cheek by jowl. But now there is no reason why some of the small towns thirty miles or more from central London should not be made integral parts of London by the provision of fast surface communications. The objective should be a cellular city with as much of present London as possible at the centre and plenty of what is called environment in between the cells.

\section{Years Ago}

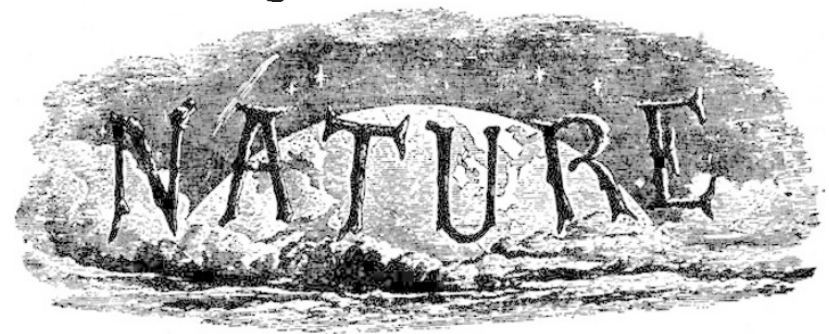

DR. E. Decaisse, in a note communicated to the Academy of Sciences on the 3 rd of June, shows that from the triple point of view of the fecundity of marriages, of the absolute number of births, and of the excess of births over deaths, France occupies the lowest place of all the European States. In Prussia 100 marriages give 460 children; in France the same number of marriages give only 300 children. In Prussia the number of births for each roo of the population generally is $3.9^{9}$ per annum ; in France there are only $2 \cdot 55$. In Prussia the. excess of births over deaths in eacl million of the population is 1 3,000 per annum, whilsc in France it only amounts to 2,400. "If we ad mit," says Dr. Decaisne, "as a conclusion from the above figurcs, that the doubling of the population of France, despsiled of two of its finest province;, and by unheard of disasters, will require 170 years to be effected, whilst that of Prussia requires only 42 years, Great Britain 52, and Russia 66, some estimate may be made of the amount of the evil that has bafallen this country." IIe does not hesitate to say that, as the first step towards the restoration of the former power of France, the first thing that should occupy her statesmen is the reconstitution, the reorganisation of human life; and everyone should throw aside that false patriotism which has been the cause of so much ill.

From Nature, 6, 250, July 25, 1872. 